\title{
Protocol
}

\section{Isolation, Culture, and Differentiation of Progenitor Cells from the Central Nervous System}

\author{
Scott R. Hutton and Larysa H. Pevny ${ }^{1}$ \\ UNC Neuroscience Center, Department of Genetics, University of North Carolina, Chapel Hill, NC 27599, USA
}

\section{INTRODUCTION}

The ability to prospectively identify and characterize neural progenitor cells in vivo has been difficult due to a lack of cell-surface markers specific for these cell types. A widely used in vitro culture method, known as the Neurosphere Assay (NSA), has provided a means to retrospectively identify neural progenitor cells as well as to determine both their self-renewal capacity and their ability to generate the three primary cell types of the nervous system: neurons, astrocytes, and oligodendrocytes. Today, combined with the establishment of multiple transgenic mouse strains expressing fluorescent markers and advances in cell isolation techniques such as fluorescence-activated cell sorting (FACS), the NSA provides a powerful system to prospectively elucidate neural progenitor characteristics and functions. Here we describe methods for the isolation, culture, and differentiation of neural progenitors from the developing mouse and adult cortex.

\section{RELATED INFORMATION}

This protocol was adapted from the method by Polleux and Ghosh (2002).

\section{MATERIALS}

CAUTIONS AND RECIPES: Please see Appendices for appropriate handling of materials marked with $<!>$, and recipes for reagents marked with $<R>$.

\section{Reagents}

Dulbecco's phosphate-buffered saline (PBS), $1 \mathrm{X}$ sterile (Sigma D8537)

$<\mathbf{R}>$ Enzyme solution for neurosphere assay (prewarmed)

$<\mathrm{R}>$ Heavy inhibitory solution (HI) (prewarmed)

Laminin stock solution $(1 \mathrm{mg} / \mathrm{mL})$ (Sigma)

Store stock solution in 0.1- $\mathrm{mL}$ aliquots at $-20^{\circ} \mathrm{C}$. Just before use (Step 14), prepare a 1:50 dilution by diluting $0.1 \mathrm{~mL}$ of stock solution in $5 \mathrm{~mL}$ of sterile 1 X PBS supplemented with $\mathrm{Ca}^{++}$and $\mathrm{Mg}^{++}$(Sigma D8662).

$<$ R $>$ Light inhibitory solution (LI) (prewarmed)

Mice (embryonic or adult)

$<$ R $>$ NEP basal medium

$<\mathrm{R}>\mathrm{NEP}$ basal medium containing $2 \%$ horse serum (Invitrogen; heat-inactivated for $30 \mathrm{~min}$ at $\left.60^{\circ} \mathrm{C}\right)$

$<\mathbf{R}>$ NEP complete medium

$<\mathrm{R}>$ Neurobasal medium (PSG)

${ }^{1}$ Corresponding author (larysa_pevny@med.unc.edu) 
<!>Paraformaldehyde (PFA; Sigma), 4\% in 1X PBS

Poly-D-lysine (Sigma)

Reconstitute in $\mathrm{H}_{2} \mathrm{O}$ for a stock solution of $1 \mathrm{mg} / \mathrm{mL}$ and store in 1.0-mL aliquots.

$<$ !>Trypsin-EDTA (Sigma) (optional; see Step 20)

\section{Equipment}

\section{Centrifuge}

Dishes, polystyrene (6- or 10-cm nontreated) (BD Falcon)

Dissection tools for removing mouse brain from skull

Forceps, sterilized (\#5 pointed) (Fine Science Tools 11252-30)

Hemacytometer

Incubator preset to $37^{\circ} \mathrm{C}$ (humidified, $5 \% \mathrm{CO}_{2}$ )

Knife, microsurgical (5-mm) (MSP/Surgical Specialties 7516)

Parafilm

Pipette (P200; P20 may be used in place of P200 in Step 20)

Plates, polystyrene, 96-well flat bottom, low cell binding (Corning 3474) (optional; see Step 21)

Razor blade, sterile

Scissors, sterilized microspring (8.5-cm) (Fine Science Tools 15009-08)

Slides, eight-well chamber (Nunc 177402)

Transfer pipettes, sterile disposable (Fisher)

Tubes, sterile conical (15- and $50-\mathrm{mL})$

Tubes, sterile microcentrifuge $(1.5-\mathrm{mL})$

Water bath preset to $37^{\circ} \mathrm{C}$

\section{METHOD}

\section{Dissection}

1. Carefully remove the brain from the skull of an embryonic or adult mouse and place in a clean dish containing ice-cold 1X PBS.

\section{To dissect tissue from an early embryo (<E16)}

i. Separate the two hemispheres of the brain. Carefully separate the region of interest (e.g., dorsal telencephalon) using a microsurgical knife (Fig. 1).

ii. Using fine-tipped forceps and a microsurgical knife, carefully remove the meninges from the tissue.

Meninges must be removed from the tissue, since they will not digest efficiently in enzyme solution.

To collect tissue from a late-stage embryo (>E16) or adult

iii. Using a razor blade, cut a coronal slice of the brain containing the region of interest (lateral ventricle, hippocampus, etc.) (Fig. 2A).

iv. Carefully remove the tissue of interest using the forceps and microsurgical knife (Fig. 2B).

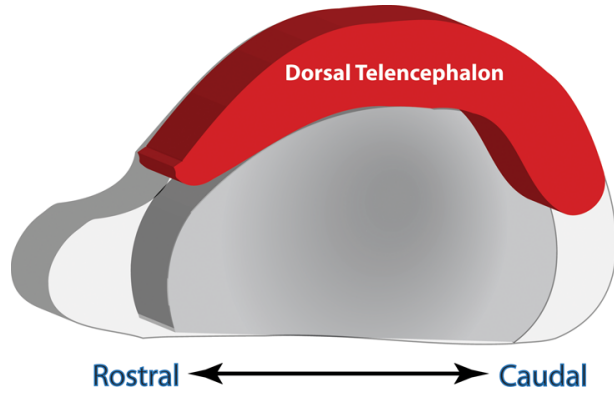

FIGURE 1. A sagittal view of a single cerebral hemisphere from an E12.5 mouse embryo, demonstrating the location of the dorsal telencephalon. 


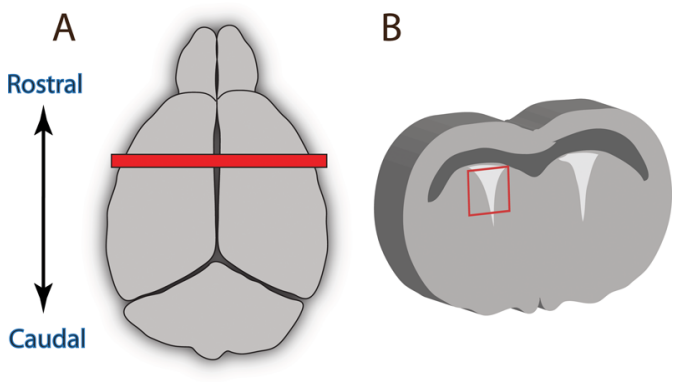

FIGURE 2. (A) Dorsal view of the adult mouse brain. The red bar indicates the location of the cut used to isolate periventricular tissue. $(B)$ The resulting cross-section of tissue with lateral ventricles exposed. Periventricular tissue should be dissected where indicated by the red box.

2. Using a sterile transfer pipette, carefully transfer the tissue to a nontreated polystyrene dish containing cold $1 \mathrm{X}$ PBS. To speed up enzymatic digestion, cut the tissue into smaller pieces using the microspring scissors.

3. Using a sterile transfer pipette, transfer the tissue to a $15-\mathrm{mL}$ conical tube containing $10 \mathrm{~mL}$ of enzyme solution. Minimize the amount of PBS transferred with the sample. Incubate at $37^{\circ} \mathrm{C}$ for 20 min, carefully mixing every $\sim 5$ min.

Do not vortex.

4. Add another $10 \mathrm{~mL}$ of enzyme solution. Incubate for $20 \mathrm{~min}$ at $37^{\circ} \mathrm{C}$, mixing occasionally. Incubation times may vary. The tissue is ready when it achieves a thick, viscous consistency.

5. In a sterile hood, carefully remove the enzyme solution using a pipette, leaving the tissue at the bottom of the tube.

6. Add $4.5 \mathrm{~mL}$ of $\mathrm{LI}$ solution to the tube. Carefully flick the tube, remove the solution, and repeat with another $4.5 \mathrm{~mL}$ of $\mathrm{LI}$ solution.

Caution: The tissue will go into solution easily and should not be mixed with a pipette.

7. Remove the LI solution, leaving the tissue at the bottom of the tube, and add $6 \mathrm{~mL}$ of HI solution. Incubate for $2 \mathrm{~min}$ at $37^{\circ} \mathrm{C}$. Gently remove the $\mathrm{HI}$ solution.

8. Add $5 \mathrm{~mL}$ of NEP basal medium, flick the tube, and remove the medium.

9. Add $0.5-1.0 \mathrm{~mL}$ of NEP complete medium and triturate $10-20$ times, until the tissue pieces are dissociated.

More medium may be required, depending upon the amount of tissue used.

10. Count the cells using a hemacytometer and add the appropriate number to a nontreated polystyrene dish containing NEP complete medium.

Cell density should be $1 \times 10^{6}$ cells per 6 -cm plate, or $2 \times 10^{6}$ cells per 10-cm plate. However, the plating density will vary between different age points and different brain regions. See Discussion.

11. Incubate cells in a humidified $37^{\circ} \mathrm{C}$ incubator $\left(+5 \% \mathrm{CO}_{2}\right)$. Monitor the dishes daily for neurosphere formation (Fig. 3A).

Adult lateral ventricle neurospheres take $\sim 1 \mathrm{wk}$ to form, while embryonic neurospheres are observed after a few days.
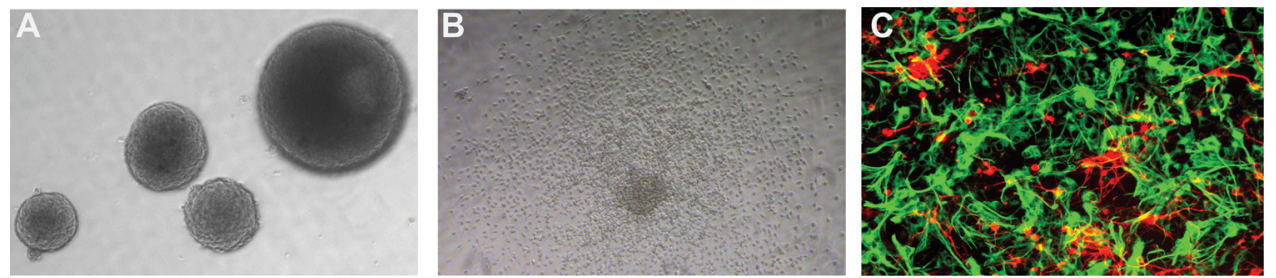

FIGURE 3. (A) Neurospheres derived from an E12.5 mouse dorsal telencephalon after $6 \mathrm{~d}$ in culture. (B) Neurosphere attachment to a poly-D-lysine/laminin-coated slide, $1 \mathrm{~d}$ after plating. (C) $\beta$-tubulin-III (red) and glial fibrillary acidic protein (GFAP) (green) labeling of neurosphere-derived neurons and astrocytes, respectively. 
12. Once spheres have formed, replace medium every $3 \mathrm{~d}$ by transferring spheres to a $15-\mathrm{mL}$ conical tube and letting them settle to the bottom by gravity at $37^{\circ} \mathrm{C}$ (centrifugation is not recommended). After the spheres have settled, remove the medium and replace with fresh NEP complete medium. Transfer spheres to a fresh dish.

\section{Slide Coating}

13. Just before use, dilute the poly-D-lysine stock solution 1:50 in $\mathrm{H}_{2} \mathrm{O}$. Add $0.2 \mathrm{~mL}$ of diluted poly-Dlysine to each well of an eight-well chamber slide. Incubate for $1 \mathrm{~h}$ at room temperature.

14. Wash wells three times with $\mathrm{H}_{2} \mathrm{O}$. Add $0.2 \mathrm{~mL}$ of diluted laminin to each well and incubate overnight at $4^{\circ} \mathrm{C}$.

Store slides at $4^{\circ} \mathrm{C}$ until use and wrap in parafilm to minimize evaporation.

15. Before use, remove laminin and wash wells once with Neurobasal medium (PSG).

Do not remove the laminin from the wells until immediately before use.

\section{Differentiation}

16. Add $100 \mu \mathrm{L}$ of NEP complete medium to each well of a poly-D-lysine/laminin-coated eight-well chamber slide (prepared as described in Steps 13-15). Transfer one sphere (from Step 12) to each well using a P200 pipette and incubate overnight at $37^{\circ} \mathrm{C}$.

17. After $24 \mathrm{~h}$, ensure spheres have attached to the slide (Fig. 3B); then carefully remove medium. Add $200 \mu \mathrm{L}$ of NEP basal medium containing $2 \%$ heat-inactivated horse serum.

18. Culture for 2-3 d, changing medium daily.

19. For fixation and subsequent immunohistochemical analysis (Fig. $3 \mathrm{C}$ ), remove medium, rinse once with $1 \mathrm{X}$ PBS, and fix with $4 \%$ PFA in $1 \mathrm{X}$ PBS for $1 \mathrm{~h}$ at $4^{\circ} \mathrm{C}$.

\section{Secondary Neurospheres}

20. Using a P20 or P200 pipette, mechanically dissociate a single neurosphere in a $1.5-\mathrm{mL}$ microcentrifuge tube.

If this is difficult, incubate spheres in trypsin for $5 \mathrm{~min}$ and dissociate mechanically.

21. Centrifuge the cells at $3000 \mathrm{rpm}$ for $5 \mathrm{~min}$ and resuspend in NEP complete medium.

Plate cells individually in 96-well, low cell binding plates or bulk passage multiple spheres as described in Step 10.

\section{DISCUSSION}

The development of a cell culture system designed to isolate and propagate putative stem cells from neural tissue (Reynolds and Weiss 1992; Reynolds et al. 1992) has greatly advanced our understanding of these cell populations. This technique has not only provided a means to monitor the physical characteristics of these cells, but has also enhanced our ability to manipulate the genetic and epigenetic factors that regulate both their capacity to self-renew and to differentiate into the three defined cell types of the nervous system: neurons, astrocytes, and oligodendrocytes. In the presence of epidermal growth factor (EGF) and/or basic fibroblast growth factor (bFGF), these cell populations can be reliably expanded and maintained in the form of neurospheres and, upon removal of these growth factors, can efficiently generate the three major CNS cell types.

Advances in mouse genetic manipulation, as well as the development of more powerful analytical technologies (e.g., FACS), have resulted in the development of multiple modified protocols of the neurosphere assay. For instance, the utilization of mouse lines containing multiple targeted mutations typically generates only a small fraction of animals carrying the desired genotype. Given that the total percentage of neural stem cells can be quite small $(<0.1 \%$ in adults [Reynolds and Weiss 1992]), it is often important to maximize the yield of neural stem cells from these animals. We have found that the often-used trypsin-based enzymatic dissociation can be deleterious to cells, resulting in a high per- 
centage of cell death after isolation. Here we provide an alternative protocol utilizing the enzyme papain, which, in our hands, is more efficient and less destructive in dissociating neural tissue, and therefore provides a greater yield of viable stem cells. It should be noted, however, that we have found that culture conditions, including enzymatic incubation times and plating densities, vary between age points as well as different neural stem cell populations, and therefore may need to be determined on an individual basis.

Although historically utilized as a means to retrospectively identify neural progenitors, today the NSA can be used in the prospective isolation and propagation of neural progenitors. The generation of mouse strains expressing fluorescent proteins under the control of neural progenitor specific markers (Nestin-EGFP [Kawaguchi et al. 2001], Sox2-EGFP [Ellis et al. 2004], and hGFAP-EGFP [Zhuo et al. 1997]), coupled with the ability to efficiently isolate these cell types using FACS, has allowed the culture of highly enriched populations of neural progenitor cells, and, using the NSA, examination of the proliferative, self-renewal, and multipotential capacities of these cells in vitro.

\section{REFERENCES}

Ellis, P., Fagan, B.M., Magness, S.T., Hutton, S., Taranova, O., Hayashi, S., McMahon, A., Rao, M., and Pevny, L. 2004. SOX2, a persistent marker for multipotential neural stem cells derived from embryonic stem cells, the embryo or the adult. Dev. Neurosci. 26: 148-165.

Kawaguchi, A., Miyata, T., Sawamoto, K., Takashita, N., Murayama, A., Akamatsu, W., Ogawa, M., Tano, Y., Goldman, S.A., and Okano, H. 2001. Nestin-EGFP transgenic mice: Visualization of the self-renewal and multipotency of CNS stem cells. Mol. Cell Neurosci. 17: 259-273.

Polleux, F. and Ghosh, A. 2002. The slice overlay assay: A versatile tool to study the influence of extracellular signals on neuronal development. SCi. STKE 136: PL9 doi: 10.1126/stke.2002.136.pl9. Reynolds, B.A. and Weiss, S. 1992. Generation of neurons and astrocytes from isolated cells of the adult mammalian central nervous system. Science 255: 1707-1710.

Reynolds, B.A., Tetzlaff, W., and Weiss, S. 1992. A multipotent EGFresponsive striatal embryonic progenitor cell produces neurons and astrocytes. J. Neurosci. 12: 4565-4574.

Zhuo, L., Sun, B., Zhang, C.L., Fine, A., Chiu, S.Y., and Messing, A. 1997. Live astrocytes visualized by green fluorescent protein in transgenic mice. Dev. Biol. 187: 36-42. 


\section{Isolation, Culture, and Differentiation of Progenitor Cells from the Central Nervous System}

Scott R. Hutton and Larysa H. Pevny

Cold Spring Harb Protoc; doi: 10.1101/pdb.prot5077

\begin{tabular}{|c|c|}
\hline $\begin{array}{l}\text { Email Alerting } \\
\text { Service }\end{array}$ & Receive free email alerts when new articles cite this article - click here. \\
\hline $\begin{array}{c}\text { Subject } \\
\text { Categories }\end{array}$ & $\begin{array}{l}\text { Browse articles on similar topics from Cold Spring Harbor Protocols. } \\
\text { Cell Biology, general (1382 articles) } \\
\text { Cell Culture (301 articles) } \\
\text { Isolation ( } 34 \text { articles) } \\
\text { Laboratory Organisms, general (923 articles) } \\
\text { Mouse (437 articles) } \\
\text { Neural Cell Culture (57 articles) } \\
\text { Neuroscience, general (357 articles) } \\
\text { Stem Cells (46 articles) } \\
\text { Stem Cells, general (70 articles) } \\
\text { Transgenic Mice (139 articles) }\end{array}$ \\
\hline
\end{tabular}

